\title{
The Relationship Between Maternal Age And Pregnancy With The Incidence Of Low Birth Weight Baby At The Jaraga Sasameh Hospital Buntok 2016
}

\author{
Susanti Suhartati*1 \\ ${ }^{1}$ Sari Mulia High School Of Health Science \\ *susanti_suhartati@stikessarimulia.ac.id \\ Putri Vidiasari $\mathrm{D}^{1}$ \\ ${ }^{1}$ Sari Mulia High School Of Health Science \\ Putri_vidiasari@stikessarimulia.ac.id \\ Mardiana $^{1}$ \\ ${ }^{1}$ Sari Mulia High School Of Health Science \\ mardiana@gmail.com
}

\begin{abstract}
Objective: The Main object of this research is to know the Relationship Between Maternal Age and Pregnancy Distance With the Incidence of Low Birth Weight Baby at the Jaraga SasamehHospital Buntok.

Methods: This kind of this research user analytic with case-controlapproachof retrospective. The subjects of this study were all infants treated at the Jaraga Sasameh Hospital Buntok which amounted to 480 babies, with a sample of case 98 and the control samples of 98 infants. The sampling technique in the case sample was taken with total sampling and the control sample was determined by systematic random sampling. The data collection through secondary data using thechecklist and this study using univariate and bivariate analysis.

Results : From result of Chi-Square Test found that there was a correlation between maternal age and mortality of LBW pvalue $0.000(<0,05)$ value of OR $11,912(95 \%$ CI $6,021-23,565)$ and there was correlation of pregnancy distance with occurrence of BBLR pvalue $0,000(<0,05)$ value of OR 24,470 (95\% CI 10,500-66,417).

Conclusion: Based on the results of the study it can be concluded that there is a relationship between maternal age and distance pregnancy with the incidence of LBW.
\end{abstract}

Keywords: Age of Mother, Baby, Low Birth Weight, Pregnancy distance

\section{INTRODUCTION}

Infant Mortality Rate (IMR) in Indonesia is still high. In the world, as 34 per 1,000 live births, IMRs in developing countries are 37 per 1,000 live births and IMR in developed countries 5 per 1,000 live births. The IMR in East Asia 11 per 1,000 when compared to the 2007

IDHSrecorded 34 per 1000 live births, but infant mortality rate (IMR) in Indonesiarelatively is stillhigh compared to ASEAN countries such as Singapore (3 per 1000 live births), Brunei Darussalam (8 per 1000 live births), Malaysia (10 per 
live births, South Asia 43 per 1,000 live births, Southeast Asia 24 per 1,000 live births and West Asia 21 per 1,000 live birthsThe number of SDGs targets an IMR of 2030 to 12 for 1,000 live births but according to IDHS 2012 recorded an IMRof 32 per 1000 live births this is decreased

Medical Center, birth weight was associated negatively with infant mortality with low birth weight [1]. The number of LBW in Indonesia reached 350,000 babies every year. The cause of LBW is generally multifactorial, sometimes it is difficult to take precautions. However, the most common cause of LBW is premature birth. The younger the pregnancy, the greater the short-term and long-term risk can occur. Factors associated with LBW infants in general, include; maternal disease (hypertension, anemia, preeclampsia / eclampsia), age $<20$ years or $>35$ years, parity, distance of pregnancy too close, history of LBW, socioeconomic, cigarette, alcohol, narcotics, chromosomal disorders (autosomal trisomy) chronic (cytomegaly inclusion, congenital rubella), familial dysautonomia, radiation, multiple pregnancy, pancreas aplasia, placental factors, and environmental factors.

In 2014, the number of cases of LBW as 535 cases $(1.60 \%)$ of live births, this number bigger when compared with the number of cases of LBW in 2013 of 484 cases (1.20\%) [2]. Based on a preliminary
1000 live births), Vietnam (18 per 1000 live births), and Thailand (20 per 1000 live births). LBW is the birth weight less than 2,500 grams. Neonatal with LBW at risk of death 6.5 times greater that in babiesborn with normalweight.In astudy from Beilinson

study conducted inJaraga Sameh General Hospital Buntok in obtaining data in the year 2013 the occurrence of BBLR 89 cases of LBW (15.5\%) of 574 total babies treated, in 2014 found 91 (17.8\%) LBW incidence of 509 treated babies, 418 $(82.1 \%)$ babies with normal weight, while in 2015 the number of LBW incidence still not resolved even it increased when compared to 2014 that is as $103(20.3 \%)$ birth of LBW of 505 total infants which was treated while the incidence of Low Birth Weight Infant in 2016 was 98 (20.4\%) BBLR of 480 babies treated at Sasameh Buntok Hospital.Based on the above description then conducted a study on Maternal Age and Distance of Pregnancy with BBLR occurrence in Jaraga Sasameh General Hospital Buntok in 2016 .

\section{RESEARCH METHOD}

The population in this study were all newborns treated at Jaraga SasamehHospital Buntok in 2016. In this study the sample was taken with two techniques. Total sampling for case samples and systematic random sampling 
for control samples with a sample ratio of one to one. Total sample of the casewas taken 98 case samples (infant having BBLR) and 98 control samples (infants not BBLR) so the total sample was 196.This research uses Analytic Survey with CaseControl approach which is an analytic (survey) research about how risk factors are studied by using retrospective research design.The study was conducted in March of 2017 based on newborn medical record data treated at Jaraga Sasameh General Hospital Buntok from January to December of 2016.

The variable used in this research is Dependent Variable that is the occurrence of BBLR. And Independent Variable of Mother Age and Distance of Pregnancy.Data was collected through secondary data using a checklist, and this study used univariate analysis and bivariate analysis with chi-square statistic test.

\section{RESULTS}

Univariate Analysis

1. Mother Age

Table 1 Frequency Distribution of Pregnant Women Age

\begin{tabular}{|c|c|c|c|c|c|}
\hline \multirow{2}{*}{$\begin{array}{l}\text { Mother } \\
\text { Age }\end{array}$} & \multicolumn{2}{|c|}{ Case } & \multicolumn{2}{|c|}{ Control } & \multirow[t]{2}{*}{ Total } \\
\hline & $\mathrm{F}$ & $\%$ & $\mathrm{~F}$ & $\%$ & \\
\hline Risk & 70 & 71,4 & 17 & 17,3 & 44,3 \\
\hline No Risk & 28 & 28,5 & 81 & 82,7 & 55,6 \\
\hline Total & 98 & 100 & 98 & 100 & 100 \\
\hline
\end{tabular}

Based on table 1 above, it can be interpreted that in the sample cases the number of mothers aged $<20$ and $>35$ years ie 70 people $(71.4 \%)$ and Mother Age 20-35 years of 28 people (28.5\%). For samples Control of mothers with age $<20$ and $>35$ years old were 17 people $(17,3 \%)$ and mother with age 20-35 years counted 81 people $(82,7 \%)$.

2. Pregnancy Distance

Table 2 Frequency Distribution PregnancyDistance

\begin{tabular}{llllll}
\hline Pregnancy & \multicolumn{2}{l}{ Case } & \multicolumn{3}{l}{ Control } \\
\cline { 2 - 5 } Distance & $\mathrm{F}$ & $\%$ & $\mathrm{~F}$ & $\%$ & Total \\
\hline$<2$ years & 62 & 63,3 & 6 & 6,1 & 34,7 \\
\hline$>2$ years & 36 & 36,7 & 92 & 93,9 & 65,3 \\
\hline Total & 98 & 100 & 98 & 100 & 100 \\
\hline
\end{tabular}

Based on table 2 above, it can be interpreted that in the case sampletotal number of mothers with distance of pregnancy $<2$ years counted 62 people $(63,3 \%)$ and mother with a distance of pregnancy $>2$ years counted 36 people $(36,7 \%)$. For control sample of a mother with distance of pregnancy $<2$ years counted 6 people $(6,1 \%)$ and mother with a distance of pregnancy $>2$ years counted 92 person $(93,9)$. 
Bivariate Analysis

1. Relation of Mother Age with LBW

Table 3 Results of the Analysis of

Maternal Age Analysis with LBW

incidence between the Distance of Pregnancy with the incidence of LBW.

\begin{tabular}{|c|c|c|c|c|c|}
\hline \multirow{3}{*}{$\begin{array}{l}\text { Mother } \\
\text { Age }\end{array}$} & \multicolumn{2}{|c|}{$\begin{array}{l}\text { Incidence } \\
\text { Weight }\end{array}$} & Lov & Birth & \multirow{3}{*}{ Total } \\
\hline & \multicolumn{2}{|c|}{ Case } & \multicolumn{2}{|c|}{ Control } & \\
\hline & $\mathrm{F}$ & $\%$ & $\mathrm{~F}$ & $\%$ & \\
\hline Risk & 70 & 35,7 & 17 & 8,7 & 44,4 \\
\hline No Risk & 28 & 14,3 & 81 & 41,3 & 55,6 \\
\hline Total & 98 & 50 & 98 & 50 & 100 \\
\hline
\end{tabular}

Based on the results in table 3 Chisquare test results obtained Pvalue 0,000 $<0,05$ and OR value of 11.9 so it can be concluded that there is a relationship between mother age with the incidence of LBW.

2. Relation of Pregnancy Distance to LBW

Table 4 Results of the Analysis of Pregnancy Distance with LBW

\begin{tabular}{|c|c|c|c|c|c|c|c|}
\hline \multirow{4}{*}{$\begin{array}{l}\text { Pregnancy } \\
\text { Distance }\end{array}$} & \multicolumn{4}{|c|}{ Incidence of Low Birth } & \multirow{4}{*}{ Total } & $\bar{P}$ & OR \\
\hline & \multirow{2}{*}{\multicolumn{2}{|c|}{ Case }} & \multicolumn{2}{|c|}{ Weight } & & \multirow[t]{2}{*}{ Value } & \multirow[t]{2}{*}{$(95 \% \mathrm{CI})$} \\
\hline & & & & & & & \\
\hline & $\mathrm{F}$ & $\%$ & $\mathrm{~F}$ & $\%$ & & \multirow{3}{*}{0,000} & 24,407 \\
\hline Risk & 62 & 31,6 & 6 & 3,1 & 34,7 & & $(10,500-$ \\
\hline No Risk & 36 & 18,4 & 92 & 46,9 & 65,3 & & $66.417)$ \\
\hline Total & 98 & 50 & 98 & 50 & 100 & & \\
\hline
\end{tabular}

Based on the results in table 4 Chisquare test results obtained value $\mathrm{P}$ value $0,000<0.05$ and OR value of 24.4 so it can be concluded that there is a relationship

\section{DISCUSSION}

\section{Low Birth Weight Baby}

CI) are categorized as low-weight babies

[4]. The cause of LBW is generally 0,000 (6,021- multifactorial, sometimes it is difficult 23,565) to take precautions. However, the most common cause of $\mathrm{LBW}$ is premature birth [4]. The younger the pregnancy the greater the short-term and long-term risk can occur. The factors associated with LBW infants in general, include; maternal disease (hypertension, anemia, preeclampsia / eclampsia), age $<20$ years or> 35 years, parity, the distance of pregnancy too close, history of LBW, socioeconomic, cigarette, alcohol, narcotics, chromosomal disorders (autosomal trisomy) chronic (cytomegaly inclusion, congenital rubella), familial dysautonomia, radiation, pancreatic aplasia, placental factors, and environmental factors [4].

The birth weight is very important because it is closely related to the survival of the next baby. Low Birth Weight will increase infant morbidity and mortality, low birth weights (LBW) that are not handled properly can lead to problems in all organ systems of the 
body, mental and physical disorders and subsequent flower development [5].

2. Mother Age Relation with Low Birth Weight Infant

In the case sample the number of mothers who have low birth weight is 70 people $(71.4 \%)$ and those who do not experience low birthweight babies are 28 people (28.5\%). While the control sample of mother age which experienced Low Birth Weight is 17 people $(17,3 \%)$ and who did not experience Low Birth Weight which is 81 people $(82,7 \%)$.

Chi-square statistic test obtained pvalue of 0.000 indicates a significant relationship between age with the incidence of Low Birth Weight ( $p$ $<0.05)$. In addition, there was also an OR value of 1.6 (95\% CI 6.0-23,5), so it was found that maternal age $<20$ and $>35$ years was 11 times more likely to have a low birth weight baby compared with motherage range 20-35 years old.

The results of another study showed that there was a significant relationship between maternal age and LBW occurrence in RSUDZA Banda Aceh that gave birth at the age of $<20$ and $>$ 35 years had an opportunity to give birth of LBW as 10.7 times compared with mother giving birth at age 20-35 years old. This is because at the age of less than 20 years, the reproductive organs are not functioning perfectly, the mother's uterus and pelvis have not grown to reach adult size so that when pregnancy and childbirth, pregnant women are more prone to complications, and at the age of more than 35 years, there is a decline in reproductive health because the degenerative process has begun to emerge [4].Pregnancy at a young age is a risk factor due to immature maturation of reproductive organs to conceive, which may adversely affect maternal health and fetal development and growth that facilitates the occurrence of Low Birth Weight (LBW). One that causes birth with birth weight is younger age while pregnant with OR 1.98, CI 1.15-3.41. The current study shows that young mothers (less than 20 years old) are nearly twice as likely to deliver LBW babies as compared to older mothers [5], while over 35 years old despite their experience, but their body condition and health have begun to decline so it can affect intrauterine fetus and can cause birth of Low Birth Weight (LBW).

From the results of the study found in the age of 20-35 years of age as 28 people (28.6\%) gave birth to Low Birth 
Weight, this is due to other factors such as physical load factors and the economic factors of pregnant women that affect the condition of infants so that they experience weight Born Low. The significant risk factors for LBW occurrence are maternal education, smoking during pregnancy, smoking before pregnancy, daily number of cigarettes, number of cigarettes used during pregnancy, father's income and socioeconomic factors [8].Another factor is the environment and culture is still a lot of early marriage so that many mothers who are pregnant $<20$ years of age who are at too young age still lack of physical and psychological mother's readiness to accept the condition of pregnancy and less attention to pregnancy so that the cause of the birth of the baby with LBW. Besides the occurrence of unwanted pregnancies such as pregnancy out of wedlock and unplanned pregnancy causes the mother not to pay too much attention to the condition of pregnancy well resulted in LBW.

At the time of pregnancy some mothers are only concerned with the appetite of the food that should be consumed in becaus lack of knowledge of the mother about the nutritional intake that must be met during pregnancy so it can bad impact on pregnancy and fetus [11].
The prognosis of pregnancy is strongly shaped by a person's age. Too young and too old is a high-risk pregnancy. Pregnancy at a young age is a risk factor due to immature reproductive organs for pregnancy (incomplete endometrium) while at age above 35 years of endometrium is less fertile and increase the likelihood of suffering congenital abnormalities, which may result in maternal health and fetal development and growth that is being conceived.

Improvement efforts that prevent the emergence of marriage will make a significant contribution in lowering the prevalence of low birth weight [7]. In addition, efforts to continuously increase the scope of use of contraceptives will be able to reduce the number of unwanted pregnancies and also prevented the occurrence of pregnancies aged over 35 years.

3. Relationship of Pregnancy Distance with Low Birth Weight Infant In the case sample the number of risky gestational distance was 62 people $(63.3 \%)$ and the amount of non-risk gestational distance was 36 people $(36.7 \%)$ while in the control sample the number of risky pregnancy distance was 6 people $(6.1 \%)$ and the number of non-risk pregnancies was 92 (93.9\%)Chi-square statistical test 
obtained pvalue of 0.000 indicates a significant relationship between Distance Pregnancy with Low Birth Weight ( $\mathrm{p}<0.05$ ). In addition, there is also an OR value of 24.5 (95\% CI 10.5$66,4)$, so it can be seen that mothers with a $<2$ years of pregnancy distance 24 times the risk of delivering babies with LBW compared with mothers with non-risk birth spacing $>2$ years.

Mothers with <2 years gestational distance were 3.231 times more likely to deliver LBW compared with mothers with> 2 years gestational distance [12]. This is in line with the results of Statistics with Chi-Square Test where $\mathrm{df}=1 \alpha=0.05$ in get $\mathrm{X}^{2}$ count $=6.79>$ from $\mathrm{X}^{2}$ table $=3.841$ then it means there is a relationship of pregnancy distance with the incidence of LBW. This is because at the distance of pregnancy> 2 years cause the occurrence of LBW because reproductive function and nutritional needs of mothers have not been met properly [13].

The distance of pregnancy greatly affects the health of mother and fetus in the womb. Newborn mothers need 2 to 3 years to get pregnant again to recover physiologically from pregnancy and childbirth. For a pregnancy that is too close to give an indication of less ready for the uterus for implantation for the embryo [12]. The optimal gestational distance is the time constraint between pregnancy that produces the best health impact for mother and child. The nearterm pregnancy distance $(<2$ years or 24 months) is one of the risk factors in reproductive health [13]. From the result of the research, the risk of pregnancy distance to LBW shows the number of LBW cases with the risk of pregnancy at risk as 62 people $(63.3 \%)$ the high case due to the lack of knowledge of mothers such as often have a certain history such as hypertension, anemia and unwilling to visit antenatal care. In this case, mothers with high-risk pregnancies should be able to anticipate delivery of LBW by performing routine antenatal care visits with weight control, checking blood pressure and other factors such as good maternal nutritional status. In addition, the lack of participation by mothers in terms of postponement of pregnancy due to lack of knowledge and lack of information about contraception. So although some mothers who participate in family planning programs but because of less attention to the use and contra indications it causes the mother to fail in the use of contraception. It is very important to prepare for the next pregnancy. The smaller the 
distance between the two births, the greater the risk to give birth to Low Birth Weight (LBW). The incidence can be caused by complications of bleeding during pregnancy and childbirth, premature part and severe anemia, mothers experiencing nausea, severe vomiting, multiple pregnancies, chronic illness.

\section{CONCLUSION}

There was a correlation between Mother Age and Low Birth Weight event (p $<0.05)$ with an OR of $1.6(95 \%$ CI 6.023.5) and there was a relationship between Pregnancy Distance and Low Birth Weight $(\mathrm{p}<0.05)$ with an OR of $24.5(95 \%$ CI 10.5-66.4). Based on the results of the study can be concluded that there is a relationship between maternal age and distance pregnancy with the incidence of LBW.

\section{REFERENCES}

[1] Sulkes J, Fields S, Gabbay U, Hod M, Merlob P. Path analysis on the risk of mortality in very low birth weight infants. Eur $\mathrm{J}$ Epidemiol 2000. Volume 16:337-41

[2] Proverawati Atikah dan Ismawati Cahyo. (BBLR) Berat Badan Lahir Rendah. 2010. Yogyakarta: Nuha Medika.

[3] Dinas Provinsi Kalimantan Tengah.Profil Kesehatan Provinsi Kalimantan Tengah. 2014
[4] Morteza Ghojazadeh. et al. Contributing death factors in very low-birth-weight infants by path method analysis. Nigerian Medical Journal. 2014.Volume 55: 389393.

[5] Maryunani anik,dkk. Asuhan Kegawatan Dan Penyulit Pada Neonatus. 2009. Jakarta: Trans Info Medika

[6] Liza Salawati . Hubungan Usia, Paritas dan Pekerjaan Ibu Hamil dengan Bayi Berat Lahir Rendah di RSUDZA Banda Aceh. Jurnal Kedokteran Syiah Kuala . 2012. Volume 12:3

[7] Sudesh RajSharma. Low Birth Weight at Term and Its Determinants in a Tertiary Hospital Of Nepal : a Case Control Study. PLoS ONE. 2015. Volume 10(4)

[8] Stojanovic Miodrag. et al. "Maternal Smoking During Pregnancy and Socioeconomic Factor as Predicyot of Low Birth Weight in Term Pregnancies in Nis". Vojnosanitetski Pregled. 2010. Volume 67 (2) : 145-150.

[9] KhanalV, ZhaoY, SauerK . Role of antenatal care and iron supplementation during pregnancy inpreventing low birth weight in Nepal: comparison of national surveys 2006 and 2011. Arch Public Health 2014. Volume.72

[10] Rosmala Nur, Adhar Arifuddin, Redita Novilia.Analisis Faktor RisikoKejadian Berat Badan Lahir Rendah Di Rumah Sakit Umum Anutapura Palu.Jurnal Preventif, 2016. Volume 7 Nomor 1, Maret $2016: 1-64$

[11]Tuti Meihartati. 2015. Faktor Ibu yang Berhubungan dengan Kejadian Bayi Berat Lahir Rendah di RSUD Andi Abdurrahman Noor Tanah Bumbu 2015. Jurnal Delima Azhar.2017. Vol 2, No. 1: 71-77 
[12] Nelly Indrasari. Faktor Resiko Pada Kejadian Berat Badan Lahir Rendah (BBLR) di Ruang delima RSUD dr. H.Abdul Moeloek Provinsi Lampung.Jurnal
Keperawatan. 2012. Volume VIII, No. 2

[13] Mochtar Rustam. Sinopsis Obstentri Fisiologi dan Obstentri Patofisiologi. Edisi 3 Jilid I. 2011.Jakarta. EGC. 